\section{ECONOMICS}

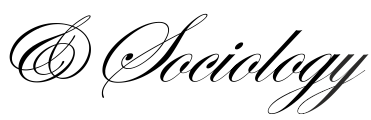

Sujarwoto. (2021). Development as happiness: A multidimensional analysis of subjective well-being in Indonesia. Economics and Sociology, 14(2), 274-293. doi:10.14254/2071-789X.2021/14-2/15

\title{
DEVELOPMENT AS HAPPINESS: A MULTIDIMENSIONAL ANALYSIS OF SUBJECTIVE WELL-BEING IN INDONESIA
}

\begin{abstract}
Sujarwoto
Brawijaya University, Indonesia

E-mail:sujarwoto@,ub.ac.id

ORCID 0000-0003-4197-4592
\end{abstract}

Received: March, 2020

1st Revision: March, 2021

Accepted: June, 2021

DOI: $10.14254 / 2071-$

789X.2021/14-2/15

\begin{abstract}
Although subjective well-being (SWB) has attracted policy-makers and researchers in the last decades, only a few studies exist on measuring the multidimensional measure of SWB and its determinants in a developing country context. In this study, we examine a multidimensional measure of SWB to identify its demographic and social determinants in Indonesia. A multidimensional measure of SWB was calculated based on the OECD SWB measure. For this analysis, we have used a unique representative national dataset, Indonesia's Happiness Survey 2017, consisting of 72,317 respondents aged 18 years and older, representing all of the country's 34 provinces. The results show that disparities in SWB exist across population groups, urban/rural groups, and the residents of various provinces and islands across the country. SWB shows consistent associations with household income, housing conditions, unemployment status, environmental quality, health status, work-life balance, social connectedness, neighborhood trust, personal security and personality. Contrasting relationships were found between SWB and household size, education and residence on certain islands. SWB may capture different information about personal well-being and quality of life than HDI and GDP. Policy makers are expected to monitor social and development progress as well as to obtain a more comprehensive understanding of quality of life in Indonesia.
\end{abstract}

JEL Classification: H04, I03, $\mathrm{O} 01$

Keywords: development, happiness, subjective well-being (SWB), multidimensional analysis.

\section{Introduction}

The ancient Greek philosopher and scientist Aristotle, who is widely considered to be one of the greatest thinkers in history, pointed out that "happiness is the meaning and the purpose of life, the whole aim and end of human existence". Thus, all of our efforts as human beings are attempts to become happy people. As Aristotle stated:

In medicine this is health, in generalship victory, in house-building a house...in every action and decision it is the end, since it is for the sake of the end that everyone does the other things...everything that is pursued into action... will be the highest 
good...and to be a good human being is to be a happy human being (Aristotle, Nichomachean Ethics 1.73 and 1.81, translated by Terence Irwin, 1985).

Following this Aristotelian logic, happiness is an intrinsic target of social development. Ironically, until 2011, most developed and developing countries were still focusing on income, particularly, per capita income and the Human Development Index (HDI) as the main indicators for evaluating social development. Governments and policy makers still fail to take happiness into account in monitoring of the social development progress (Frey, 2020, Maddux, 2017, OECD, 2013, Fleche et al., 2012). Social development scientists have long claimed that well-being analyses based on GDP and HDI provide an insufficiently detailed picture of the living conditions of ordinary people (Maddison et al., 2020, La Placa et al., 2013, Sen, 2006). This measure has been criticized because how much basic goods and services should be delivered to citizens depends on a government (Bagstad \& Fox, 2021, Gligorić Matić et al., 2020, Klugman et al., 2011). The appropriate level of basic goods and services has also been criticized (Gligorić Matić et al., 2020, Monni \& Spaventa, 2013). Yet social scientists and policy makers recommend considering happiness in evaluations of both quality of life and progress (Frey, 2020, Maddux, 2017, Dolan \& Metcalfe, 2011, Layard 2006, McGregor et al., 2009). They believe that people's experience and what they think in their lives is the fundamental element of the quality of life.

While many social scientists have attempted to develop happiness metrics, the Organization for Economic Co-operation and Development's (OECD) multidimensional measure of SWB has become a prominent assessment tool in the last decade (Morrison, 2021, Iglesias et al., 2017, OECD, 2017, Vanhoutte, 2014). The definition of a multidimensional measure of SWB proposed by the OECD consists of three elements. First, the life satisfaction element refers to a reflective evaluation of individual's life. Second, the affect element refers to a person's feelings which reflect their emotional conditions. Third, the eudaimonia element refers to a person's psychological function (Morrison, 2021, Atkinson et al., 2020, OECD, 2013). Notably, this proposed measure takes into account that an individual themselves should provide evaluation of those three elements. Thus, the views of the individuals themselves are therefore the subject of interest.

Applying the OECD's SWB measure to the data from Indonesia's National Happiness Survey, this study aims to examine Indonesians' SWB and to investigate the regional distribution in demographic and social determinants of the country's SWB. Our goal is to provide additional information on SWB using a unique national dataset. Hence, this study seeks to answer the following questions: taking into account life evaluation, affect and eudaemonic well-being, what is Indonesians' state of SWB? Which of the archipelago's provinces are home to the happiest people? How do age, sex, income status, education status, employment and health status, housing conditions, work-life balance, social connectedness, civic engagement, environmental quality and personal security relate to the Indonesians' SWB?

Indonesia is the world's third most populous developing country. It is often mentioned by the international donors and development economists for its economic development success (Talitha et al., 2020, Kurniawan \& Managi, 2018, Ranis \& Stewart, 2012). Following the Asian economic crisis back in 1999, Indonesia's economic growth and HDI have been increased substantially, while income poverty has also been substantially decreased (Idrus \& Rosida, 2020, Talitha et al., 2020, Pradhan et al., 2010, Ranis \& Stewart, 2012). However, to date, there have been only a few attempts to examine the progress of quality-of-life development in this country, especially in part of SWB. Most of the recent studies on the quality of life in Indonesia have been based on a capability approach, which focuses on the unidimensional measures such as income, health and education as well as multidimensional measures, mainly HDI and the Multidimensional Poverty Index (MPI) (Hanandita \& 
Tampubolon, 2016, Hamzah et al., 2012). Moreover, the existing studies focusing on SWB have been restricted to happiness and generalized life satisfaction as the unidimensional measures of SWB (Sujarwoto, 2019, Ngo et al., 2015, Sohn, 2013). They have been based on the Indonesian Life Survey (IFLS) data, the main limitation of which is that this survey covers only $83 \%$ of the country's population and neglects people living in poor regions of the archipelago since the survey has been focused on the Western Indonesia which is relatively well-developed (Sujarwoto, 2018, 2019, Strauss et al., 2016).

This study addresses the aforementioned research gaps in two ways. First, it goes beyond happiness and life satisfaction as the unidimensional measures of SWB. This study is the first to use a multidimensional measure of SWB, consisting of its three components - life evaluation, affect and eudaemonic well-being - to measure the SWB in Indonesia. We are thus able to capture the nuances of SWB, which are considered better adapted to policy and research questions. Secondly, in estimating these three components of SWB, the present study uses a large and nationally representative dataset which covers the whole regions of the country. The National Socioeconomic survey dataset is a primary source of information used by policy makers and international observers for monitoring social development progress of the country. We concur with the OECD, which stresses that lack of data availability has been the main hindrance in constructing an internationally comparable measure of SWB. In this study, although it uses the existing data source, we attempt to provide a substantively meaningful representation of Indonesian SWB.

\section{Literature review}

SWB has been considered by researchers and policy makers as one of key measures of development especially in developed countries (Sameet et al., 2021, Ludwigs \& Erdtmann 2019, Luhman, 2017, OECD 2013). Since 2011, OECD has included SWB to measure development progress across European countries via Better Policies for Better Life Initiatives program (D'Agostino et al., 2019, OECD, 2013). Currently, SWB has been frequently used in developed countries as one of the measures used to monitor social progress. It has been adopted as complement of Gross Domestic Products (GDP) to measure progress of social development in Europe (Cavalletti \& Corsi, 2018). This measure has also been used as a reference for policy decisions and to inform the policy debate and engage citizens such as the United Nations Human Development Index, OECD`s Better Life Index and more recently within Sustainable Development Goals (SGDs) agenda (Aksoy \& Bayram Arl1, 2020, Iriarte \& Musikanski, 2019). Although scientific debates on SWB construct and measurement have been continued among scholars (Sameer et al., 2021, Smyrlis \& Moschidis, 2018, Helliwell et al., 2013).

Among those debates, scholars highlight two measurement methods used for measuring SWB. First, unidimensional measure of SWB especially a single measure of happiness and life satisfaction (Tsurumi et al., 2020, Engelbrecht, 2019, Maddux, 2017). Although these measures have advantage such as a short, simple but comprehensive as well as accommodate personal interpretation, these measures also have limitations as its too abstract and can be misunderstood as well as influenced by specific domain of person lives (Tsurumi et al., 2020, Maddux, 2017, Helliwell et al., 2013, Kahneman \& Krueger, 2006, Diener, 2006, Seligson et al., 2003). Unidimensional measure also does not capture the nuance of person quality of live so that it is difficult to translate into policy (Engelbrecht, 2019, Skevington \& Böhnke, 2018, OECD ,2013). Second, multidimensional measure of SWB which has been argued to be a better measurement as it able to capture more nuance of people well-being and better guided for policy formulation (Lui \& Fernando, 2018, Helliwell et al., 2013, OECD, 2013). However, the multidimensional measure of SWB have some limitations such as 
longer and not simple as a consequence policy maker need more resources to apply this measure (Yang, 2018, Lui \& Fernando, 2018).

We used the OECD SWB multidimensional measure in this study. The OECD (2013) defines SWB as "good mental states, including all of the various evaluations, positive and negative, that people make of their lives and the affective reactions of people to their experiences". This definition is in agreement with recent views among scholars that explains as "an umbrella term for the different valuations people make regarding their lives, the events happening to them, their bodies and minds, and the circumstances in which they live" (Yang, 2018, Goodman et al., 2018, Maddux, 2017). Since this definition is relatively broad, there is general agreement among experts to include three components (Kushlev et al., 2020, Atkinson et al., 2020, Dolan \& Metcalfe, 2015, Sen et al., 2009). Figure 1 outlines three elements (i.e., life evaluation, affects and eudemonic well-being) of a simple measurement framework for the OECD SWB measure. Recent studies found that smaller correlation among those three elements which indicate that those three elements capture distinct meanings (Kushlev et al., 2020, Atkinson et al., 2020, Kahneman \& Krueger, 2006). The following is the explanation of each of the SWB components.

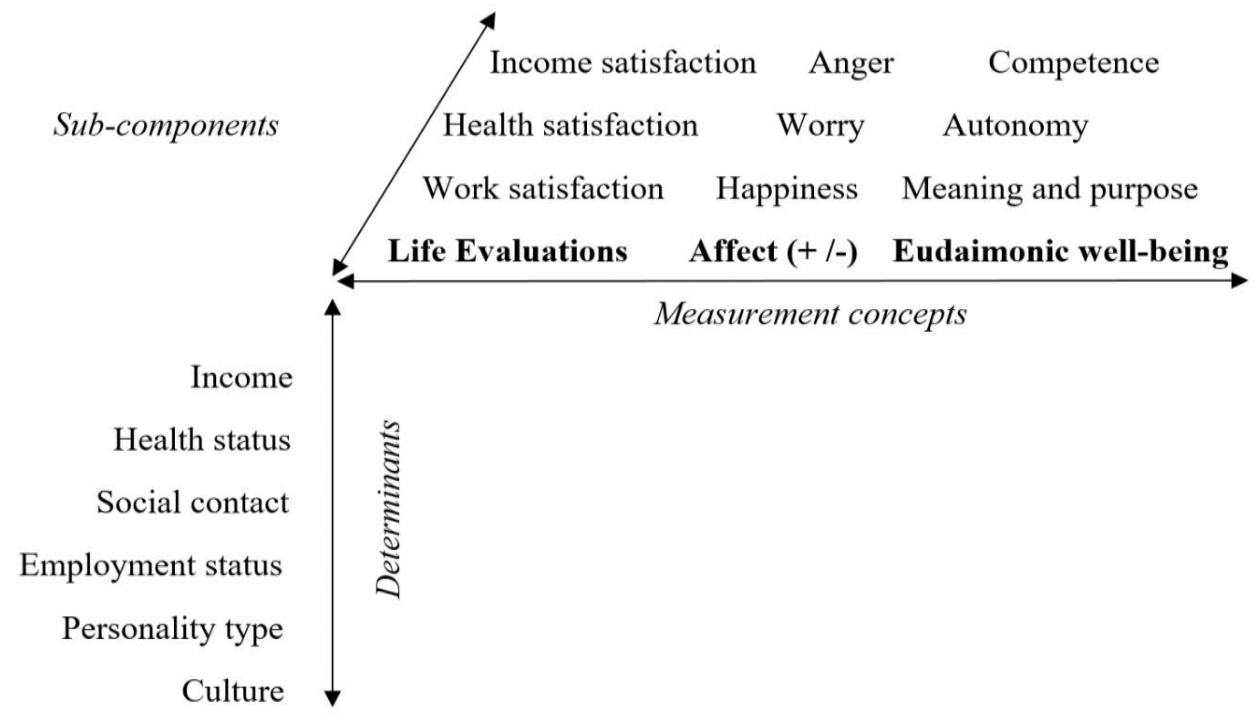

Figure 1. OECD Multidimensional SWB measure

First, life evaluation captures individual judgement of their life. Scholars explain that life evaluation can be person evaluation of their whole life or some specific aspects of their life such as income, health, education and job (Ng \& Diener, 2019, Deaton, 2018, Ganzach \& Yaor, 2019, Kahneman et al., 2006). Life evaluation does not describe person emotional state, but it rather describes person experiences of their "life as a whole", which can be substantially differ with person actually experience something at one point of time. Hence, social scientists agreed that life evaluation align with the concept of individual welfare and therefore they are keen to use as a proxy to measure citizen welfare ( $\mathrm{Ng} \&$ Diener, 2019, Deaton, 2018, Ganzach \& Yaor,). Żemojtel-Piotrowska et al. (2017) for example used "The Personal Wellbeing Index" which captures eight aspects of person life evaluation. These eight aspects of person life evaluation have strong correlation with overall life evaluation indicating each of indicators explaining the overall person life assessment (Kahneman \& Krueger, 2006, OECD, 2013, Diener et al., 1999). More recently, scholars proposed a holistic and a hybrid well-being approach which combine objective and subjective measure of well-being (Kwarciński \& 
Ulman, 2020, D'Silva \& Samah, 2018). Another scholar focuses on the idea of social justice as an additional measure of life evaluation especially to account for the effectiveness of public distributive policy (Mishchuk et al., 2019). All these measures provide useful guidance for policy makers to monitor and evaluate development progress.

Second, affect which refers to person's feelings in a particular point in time (Pancheva et al., 2020). Therefore, this element is often measured with reference of person's emotional state in a particular point in time. Difference with the concept of live evaluation, affect reflects experience of individual' life which could be positive or negative experience (Mackenzie et al., 2018, Pancheva et al., 2020). Thus, affect element of SWB consist of those two hedonic dimensions. Positive affect captures person positive feelings, such as joy and happiness. On the other hand, negative affect which captures person negative feelings such as fear, anxiety, anger and sadness (Mackenzie et al., 2018). Kahneman \& Krueger (2006) explain that positive affect is often measured by unidimensional indicator as among its indicators are strongly corelated, while negative affect is often measured by multidimensional indicators due to among its indicators capture distinct person's emotional states (Jayawickreme et al., 2017). For example, someone may feel angry but in the same time they do not sad or fear.

Third, eudemonic element of SWB refers to person psychological functioning (Sirgy, 2020, Pancheva et al., 2020). Eudemonic well-being captures realization of individual potential rather than assessment of their life evaluation and feelings or emotional states (Pancheva et al., 2020). Eudemonic element of SWB differs with life evaluation and affect elements as this element focuses on individual capabilities (Sirgy, 2020). Huppert et al. (2009) eudemonic SWB comprises eight individual capabilities: autonomy, resilience, altruism, competence, goal orientation, sense of purpose, social engagement, caring and altruism.

\section{Methodological approach}

\subsection{The Indonesia Happiness Survey 2017}

This study used data from Indonesia's Happiness Survey 2017, which was the first national survey to measure the SWB of Indonesia's population (BPS, 2017b). The survey was integrated with Indonesia's National Household Survey, which is used by government and policy makers for the monitoring and evaluation of progress in national and regional quality of life. The survey collected basic socioeconomic and demographic information, information on material conditions such as household income, household consumption, deprivation and quality of housing, and some quality-of-life indicators such as employment status, health status, education and skills, work-life balance, social connectedness, housing and environment quality and personal security. The survey targeted individuals 18 and older living in all of Indonesia's 34 provinces. It was designed to be representative at the provincial level. Overall, the total sample size required to estimate well-being at the provincial level was 75,000 households. Samples were collected based on two-stage, one-phase random sampling. The survey was conducted from April 5 to April 30, 2017 in all 34 of Indonesia's provinces and collected information from 72,317 households, or $96 \%$ of the targeted sample (BPS, 2017b). The survey used computer-assisted personal interviewing (CAPI) with show cards. This method of data collection has been considered the most suitable method for collecting SWB related data (OECD, 2013). 


\subsection{SWB measures}

The main outcome variable is SWB, which is based on the OECD SWB indicators (OECD, 2013). SWB encompasses three components: life evaluation, affect, and eudemonic element of well-being. The life evaluation aspect was divided into two components: personal life satisfaction, consisting of five questions to evaluate respondents' assessments of their education and skills, job, income, health, and house and its facilities, and social life satisfaction, consisting of five questions to evaluate respondents' assessments of their personal relationships, free time, feeling of community, quality of environment and safety. Positive and negative affect were measured by means of three questions to capture respondents' emotions related to enjoyment, worry and depression. Eudemonic well-being was measured by six questions assessing good psychological functioning as represented by autonomy, competence, sense of purpose, resilience, social engagement, caring and altruism (BPS, 2017a). The data were collected by trained interviewers who understand each concept of SWB and techniques for collecting each of the SWB data. During the interviews, the interviewers used a supported device in the form of rating scale images showing a ladder of life scale from 0 to 10 anchored by verbal labels representing scores. In the area of life evaluation, 0 meant "completely dissatisfied" and 10 meant "completely satisfied," with regard to affect, possible responses ranged from "all the time" to "not at all," and for eudemonic well-being, 0 meant "disagree completely" and 10 meant "agree completely." To obtain accurate reports of affect, they were reported after a period of approximately 24 hours (BPS, 2017a).

\subsection{Demographic and social determinants of $S W B$}

We included some standard demographic and social determinants of SWB that have often been used in previous research. The demographic determinants included age, sex, urban/rural location and island of residence. Age was divided into four categories (18-24 years old, 25-40 years old, 41-59 years old and 60 and older) with respondents under 25 years old as the reference. Marital status was divided into two categories: married and widowed/divorced. Urban or rural location was also included, with urban as the reference variable. The island categories were Sumatra, Java (reference), Nusa Tenggara, Kalimantan, Sulawesi, Maluku and Papua.

Social determinants include income, education and skills, housing quality, employment, health, work-life balance, social connectedness, civic engagement, environmental quality, personality and their security. Household income is a consistent predictor of SWB (Lane, 2000). In this study, income was categorized into five quintiles, with the first quintile as the reference. Scholars found a positive association of education on SWB (Di Tella et al., 2003, Helliwell, 2003). Education was categorized based on completion of the levels of Indonesia's educational system. We used elementary school as reference category. We also used a dummy variable indicating whether or not respondents had a skill certificate to capture the relationship of access to skill training and SWB.

Housing quality captures material conditions where individual live. Studies found housing conditions affect SWB (Oswald \& Wu, 2010). In this study, housing quality was measured by whether respondents' homes had ceramic or wood floors, wood or concrete walls, terracotta or slate tiles, electricity, sanitation and clean water. Employment status is well documented to have a significant influence on SWB, with unemployment in particular harms for happiness and life satisfaction (Boarini et al., 2016). Poor health and illness, both mental and physical, diminish well-being (Diener et al., 2018). To measure mental health status, we used 10 items indicating respondents' experience of the following mental health 
symptoms: having a headache, having an eating disorder, having a sleep disorder, feeling lonely, feeling worried, feeling afraid, feeling lazy about doing daily activities, having digestive issues, getting tired quickly, and thinking about ending life. Physical health issues were measured by questions asking whether respondents had problems hearing, seeing, walking/climbing stairs and whether respondents had difficulties in remembering, concentrating and communicating with others. We also included healthy lifestyle practices to examine whether respondents who engage in regular physical activity, have healthy diets, sleep enough, drink vitamins and have regular medical check-ups have better SWB.

Prior studies have found aspects of work/life balance to have an impact on SWB (Kahneman \& Kruger, 2006). Work/life balance was measured in this study to examine respondents' balance between working and free time/relaxation as well as whether respondents were able to use their free time for watching TV, videos, and movies or listening to music or karaoke, reading newspapers, magazines, and books, playing sports, chatting with neighbors, and recreation and individual hobbies. Social connectedness is one of the most important factors in SWB (see for example, Helliwell \& Wang, 2010, Kahneman \& Kruger, 2006). In this study, social connectedness was measured by whether respondents were able to meet and communicate with their families regularly, spend time with their spouses and children, and feel respected by their families as well as whether respondents felt bereft of friends (reversed), felt isolated in the community (reversed), and felt left behind by the community (reversed). Civic engagement has also been found to be associated with SWB (Helliwell \& Wang, 2010, Frey \& Stutzer, 2005). In this study, civic engagement was measured by neighborhood trust as well as democratic participation in the community. We used questions about trusting close neighbors, religious leaders, community leaders, and members of other ethnicities and religious groups to measure neighborhood trust. Democratic participation in the community was measured by questions as to whether respondents actively participated in community parliament meetings, sporting activities, social activities, and religious activities within their communities. Personality is important for SWB, extraverted individuals tend to be happier (Visser \& Pozzebon, 2013). To measure personality, the Indonesia's happiness survey 2017 whether they considered themselves to be friendly and sociable as well as whether they were able to accept what they have. Environmental quality was measured by respondents' evaluations of the presence of water and air pollution in the past month in their areas. A sense of security is important to SWB, as reflected in the correlations between the experience of victimization and SWB (Boarini et al., 2012). The Indonesia's happiness survey 2017 used a question whether respondents or their family members had been the victims of crimes.

\subsection{Statistical analysis}

Firstly, we adopted the Oxford Poverty and Human Development Initiative's (OPHI) Multidimensional Poverty Index (MPI) method to calculate multidimensional SWB (Alkire \& Foster, 2011). Although each of SWB elements deliver detail and rich information when measured and reported separately, a single overarching index of SWB would be benefits for policy makers for monitoring development progress (Stiglitz et al., 2009). For this purpose, we used a simple framework to calculate multidimensional SWB. In this framework, each individual $i$ considers the dimensions of well-being $m$. Fulfillment in dimension $k$ for individual $i$ is measured with a SWB positive real number $\mathrm{x}_{i k}$ and the personal fulfillment bundle of individual $i$ is an $m$ dimensional vector $\mathrm{x}_{i}=\left(\mathrm{x}_{i 1}, \mathrm{x}_{i 2} \ldots \mathrm{x}_{i m}\right)$. Here, the multidimensional SWB indices are used only for information on attainment $\mathrm{x}_{i k}$. Multidimensional SWB is notated as: 


$$
\operatorname{MSWB}\left(\bar{x}_{i k}, w_{k}\right)=\left\{\begin{array}{cl}
\left(\sum_{k=1}^{m} w_{k}\left(\bar{x}_{i k}\right)^{p}\right) 1 / p & p<1, p \neq 0 \\
\coprod_{k=1}^{m}\left(\bar{x}_{i k}\right)^{w_{k}} & p=0
\end{array}\right.
$$

Where $M S W B$ is multidimensional SWB defined as a weighted generalized mean of order $p$, where $\mathrm{x}_{i k}$ is the average of person fulfillments in dimension $k$, and where $\mathrm{w}_{k}$ is weight of dimension $k$ where $\sum_{k=1}^{m} w k=1$. Here, all dimensions of SWB are equally weighted and the population-level average $\mathrm{x}_{i k}$ is referred to the arithmetic mean of person fulfillment $\mathrm{x}_{i k}$ in dimension $k$. Secondly, since the SWB measure and its components are continuous variables, we used ordinary least squares (OLS) regression to examine the association of demographic and social determinants of SWB and its components. Robustness analyses are conducted by plotting SWB measure with Human Development Index (HDI) and GDP data across 34 Indonesian provinces. HDI data and GDP data are retrieved from Indonesian Central Bureau of Statistics (2018).

\section{Conducting research and results}

\subsection{Descriptive statistics}

Tables 1 and 2 present the descriptive statistics of the sample and calculation results of the SWB measures. The average age of the respondents was 47 years old. Most respondents were in the 41- to 59-year-old category. About $62 \%$ of respondents were male, and most of them were married $(82 \%)$, while $12 \%$ of them were widowed and $6 \%$ of them were divorced. Most of respondents lived in rural areas (54\%) and on Jawa Island (61\%). About one third of respondents had incomes of less than 1.8 million rupiah (130 USD) per month. Thirty-seven percent of respondents were educated to the elementary school level. Only $11 \%$ had completed university. Most reported that the conditions in their homes were good $(64 \%)$. Seven percent of respondents had been unemployed in the previous month. The mean of mental health symptoms was 16 while the mean of physical health issues was 5, indicating that most of the respondents were having moderate mental and physical health issues.

Respondents reported regular engagement in at least three healthy activities. Respondents also reported that they were able to do most of the relaxing activities mentioned in their free time. Most reported having good family relationships and did not feel lonely or left behind. They had relatively high levels of trust in their neighbors, but they were not very active in participating in community activities. Most of them said that they were friendly and sociable people who were able to accept what they had. Only a very small number of respondents reported facing air and water pollution in their living areas. Likewise, only 5\% reported having been crime victims in the previous year. 
Table 1. Summary statistics of sample

\begin{tabular}{|c|c|c|c|c|}
\hline Variables & Mean $(\%)$ & SD & Min & Max \\
\hline$S W B$ & 6.89 & 0.9 & 2.11 & 9.78 \\
\hline Life evaluations & 7.11 & 0.33 & 2.33 & 9.33 \\
\hline Affect & 6.66 & 0.46 & 2.33 & 9.11 \\
\hline Eudemonic & 6.91 & 0.4 & 2 & 9.33 \\
\hline \multicolumn{5}{|l|}{ Demographics } \\
\hline Age & 46.71 & 18.63 & 18 & 90 \\
\hline $18-24$ & $4 \%$ & & 0 & 1 \\
\hline $25-40$ & $32 \%$ & & 0 & 1 \\
\hline $41-59$ & $46 \%$ & & 0 & 1 \\
\hline 60 and older & $18 \%$ & & 0 & 1 \\
\hline Male & $62 \%$ & & 0 & 1 \\
\hline Household size & 3.81 & 1.68 & 1 & 19 \\
\hline Married & $82 \%$ & & 0 & 1 \\
\hline Divorced & $3 \%$ & & 0 & 1 \\
\hline Widowed & $12 \%$ & & 0 & 1 \\
\hline Rural & $54 \%$ & & 0 & 1 \\
\hline Java & $61 \%$ & & 0 & 1 \\
\hline Sumatra & $21 \%$ & & 0 & 1 \\
\hline Nusa Tenggara & $4 \%$ & & 0 & 1 \\
\hline Kalimantan & $6 \%$ & & 0 & 1 \\
\hline Sulawesi & $7 \%$ & & 0 & 1 \\
\hline Maluku & $1 \%$ & & 0 & 1 \\
\hline Papua & $1 \%$ & & 0 & 1 \\
\hline \multicolumn{5}{|l|}{ Income status } \\
\hline $1^{\text {st }}$ income quintile & $30 \%$ & & 0 & 1 \\
\hline $2^{\text {nd }}$ income quintile & $22 \%$ & & 0 & 1 \\
\hline $3^{\text {rd }}$ income quintile & $19 \%$ & & 0 & 1 \\
\hline $4^{\text {th }}$ income quintile & $16 \%$ & & 0 & 1 \\
\hline $5^{\text {th }}$ income quintile & $13 \%$ & & 0 & 1 \\
\hline \multicolumn{5}{|l|}{ Education and skills status } \\
\hline Elementary school & $37 \%$ & & 0 & 1 \\
\hline Junior secondary school & $27 \%$ & & 0 & 1 \\
\hline High school & $25 \%$ & & 0 & 1 \\
\hline University & $11 \%$ & & 0 & 1 \\
\hline Having skill certificate & $19 \%$ & & 0 & 1 \\
\hline \multicolumn{5}{|l|}{ Housing conditions } \\
\hline Good housing conditions & $64 \%$ & & 0 & 1 \\
\hline \multicolumn{5}{|l|}{ Employment status } \\
\hline Unemployed & $7 \%$ & & 0 & 1 \\
\hline \multicolumn{5}{|l|}{ Health status } \\
\hline Number of mental health symptoms present & 16.27 & 3.61 & 13 & 52 \\
\hline Number of physical health issues present & 4.67 & 1.96 & 2 & 12 \\
\hline Healthy lifestyle practices & 2.78 & 1.84 & 0 & 4 \\
\hline \multicolumn{5}{|l|}{ Work/life balance } \\
\hline Ratio of working hours to hours of relaxation & 2.79 & 3.25 & 0 & 12 \\
\hline Ability to do relaxing activities during free time & 6.42 & 1.20 & 1 & 9 \\
\hline \multicolumn{5}{|l|}{ Social connectedness } \\
\hline Good family relationship & 9.95 & 1.22 & 3 & 12 \\
\hline Feeling lonely and left behind & 3.16 & 0.69 & 3 & 12 \\
\hline \multicolumn{5}{|l|}{ Civic engagement } \\
\hline Having trust in the neighborhood & 33.79 & 4.06 & 14 & 57 \\
\hline Participation in community activities & 23.59 & 9.42 & 8 & 131 \\
\hline \multicolumn{5}{|l|}{ Personality } \\
\hline Being a friendly and sociable person & 9.30 & 1.93 & 0 & 13 \\
\hline Being able to accept what one has & 7.99 & 1.45 & 0 & 11 \\
\hline
\end{tabular}




\begin{tabular}{|c|c|c|c|c|}
\hline \multicolumn{5}{|l|}{ Environmental conditions } \\
\hline Reported air and water pollution & $1 \%$ & & 0 & 1 \\
\hline \multicolumn{5}{|l|}{ Personal security } \\
\hline Being a victim of crime & $5 \%$ & 0.35 & 0 & 1 \\
\hline
\end{tabular}

Source: own compilation.

Table 2. Unidimensional and multidimensional measures of SWB

\begin{tabular}{lrr}
\hline \multicolumn{1}{c}{ SWB components } & Mean & SD \\
\hline \multicolumn{1}{c}{ Life evaluations } & & \\
\hline Personal life satisfaction & 5.90 & 2.00 \\
\hline S1: How satisfied are your with your education and skills? & 6.60 & 1.80 \\
\hline S2: How satisfied are you with your job? & 6.40 & 1.90 \\
\hline S3: How satisfied are you with your income? & 7.20 & 1.70 \\
\hline S4: How satisfied are you with your health? & 6.90 & 1.80 \\
\hline S5: How satisfied are you with your home and its facilities? & 6.60 & 1.50 \\
\hline Total personal satisfaction & & \\
\hline Social life satisfaction & 8.00 & 1.40 \\
\hline S6: How satisfied are you with your personal relationships? & 7.20 & 1.50 \\
\hline S7: How satisfied are you with the amount of time you have to do the things that you like doing? & 7.50 & 1.30 \\
\hline S8: How satisfied are you with feeling part of your community? & 7.70 & 1.50 \\
\hline S9: How satisfied are you with the quality of your local environment? & 7.70 & 1.50 \\
\hline S10: How satisfied are you with how safe you feel? & 7.62 & 0.90 \\
\hline Total social life satisfaction & 7.11 & 1.00 \\
\hline Life evaluations & & \\
\hline Positive/negative affect & 7.40 & 1.40 \\
\hline A1: How much enjoyment do you experience? & 6.27 & 1.90 \\
\hline A2: How much worry do you experience? [reversed] & 6.30 & 2.10 \\
\hline A3: How much depression do you experience? [reversed] & 6.66 & 1.40 \\
\hline Positive/negative affect & 6.90 & 1.50 \\
\hline Eudemonic well-being & 7.10 & 1.30 \\
\hline E1: I am free to decide for myself how to live my life & 6.30 & 1.80 \\
\hline E2: In general, I feel very positive about myself & 7.18 & 1.30 \\
\hline E3: I am able to develop my potential & 7.00 & 1.40 \\
\hline E4: I generally feel that what I do in my life is worthwhile & 7.00 & 1.30 \\
\hline E5: I am always optimistic about my future & 6.91 & 1.10 \\
\hline E6: I am able to accept what I have & 6.89 & 1.10 \\
\hline Eudemonic well-being & & \\
\hline Total SwB &
\end{tabular}

Source: own compilation.

Overall, the SWB of Indonesians in 2017 was relatively good (as indicated by the mean score of family well-being at 6.89 within the range 1 to 10). The mean of life evaluation was the highest, while the positive and negative affect was the lowest. Among the SWB items, the mean of personal relationships was the highest, while the lowest mean was that of respondents' satisfaction with their education and skills. Variations in SWB measures also appear across the provinces. Figure 2 illustrates the geographical distribution of SWB among the 34 Indonesian provinces. Families living in the provinces of Papua, West Nusa Tenggara, Lampung and North Sumatra had the lowest levels of SWB, while families living in North Maluku had the highest levels of SWB. 


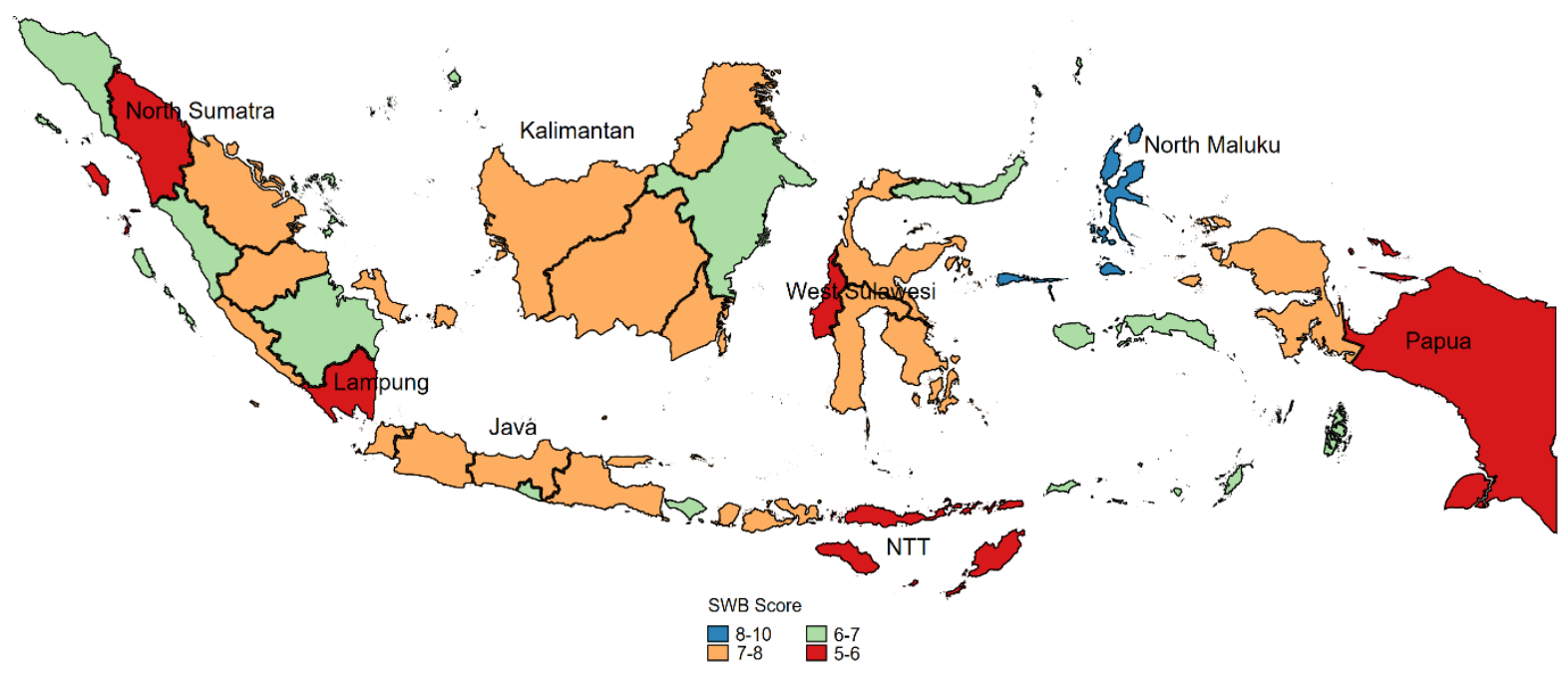

Figure 2. SWB Map of Indonesia's 34 Provinces

Source: Indonesia's National Bureau of Statistics, 2018 (Map is created by author).

\subsection{OLS results}

Table 3 shows the OLS results, explaining the association between the demographic and social determinants of SWB and its components. The associations between age category and SWB vary across the components. Significant associations were found between adulthood and older age and overall SWB, life evaluation and affect, indicating that older people have better SWB than younger people. However, null associations were shown for eudemonic well-being. Since eudaimonia refers to respondents' perceptions of living well and doing well, the null associations may indicate that age was not related to individuals' perceptions of living and doing well. Across SWB components, females had better SWB than males. The association between household size and SWB varies across SWB components.

Negative associations were found with overall SWB and affect, while a positive association was found with life evaluation. These contrasting associations may reflect different roles of household size on life evaluation and affect. However, a null association was found for eudemonic well-being. As expected, being married is good for SWB. In all SWB components, married respondents have better SWB than divorced or widowed respondents. In the Indonesian context, rural areas often denote poverty and a lack of public facilities. These conditions are reflected in the negative association between living in a rural area and SWB. Contrasting associations were found in terms of the relationships between island of residence and the three SWB components. In general, positive associations were shown for the relationships of respondents live in Sumatra, Nusa Tenggara, Sulawesi, Maluku and Papua on total SWB, life evaluation, and eudemonic well-being. In contrast, negative associations were found for the relationship between residence in those Islands and affect.

Money matters for Indonesians' SWB. On the whole, families with higher incomes have better SWB than those with lower incomes. Inconsistent relationships between educational status and SWB components were shown, especially for those educated to the junior secondary and high school levels. Positive associations were found for the relationship between university education and SWB, but the associations were significant only for total SWB, affect and eudemonic well-being. Null associations were found for the relationship between university education and life evaluation. This null association is consistent with respondents' lowest satisfaction with their education and skills as presented in the Table 3. 
Table 3. OLS regression results

\begin{tabular}{|c|c|c|c|c|c|c|c|c|}
\hline \multirow[b]{2}{*}{ Variables } & \multicolumn{2}{|c|}{ SWB } & \multicolumn{2}{|c|}{$\begin{array}{c}\text { Life } \\
\text { evaluations }\end{array}$} & \multicolumn{2}{|c|}{ Affect } & \multicolumn{2}{|c|}{ Eudaimonia } \\
\hline & Coef. & S.E. & Coef. & S.E. & Coef. & S.E. & Coef. & S.E. \\
\hline $25-40$ & 0.00 & 0.02 & 0.01 & 0.01 & 0.00 & 0.01 & 0.00 & 0.01 \\
\hline $41-59$ & $0.06^{*}$ & 0.02 & $0.04 *$ & 0.01 & 0.01 & 0.01 & 0.01 & 0.01 \\
\hline$\geq 60$ & $0.17 *$ & 0.02 & $0.10^{*}$ & 0.01 & $0.07 *$ & 0.01 & 0.01 & 0.01 \\
\hline Male & $-0.02 *$ & 0.01 & $-0.04 *$ & 0.00 & $-0.04 *$ & 0.00 & $0.06^{*}$ & 0.00 \\
\hline Household size & $-0.01 *$ & 0.00 & $0.00 *$ & 0.00 & $-0.01 *$ & 0.00 & 0.00 & 0.00 \\
\hline Married & $0.02 *$ & 0.01 & $-0.01 *$ & 0.00 & $0.02 *$ & 0.01 & $0.02 *$ & 0.00 \\
\hline Rural & $-0.03 *$ & 0.01 & $-0.01 *$ & 0.00 & $-0.02 *$ & 0.00 & 0.00 & 0.00 \\
\hline Sumatra & $0.03 *$ & 0.01 & 0.00 & 0.00 & $-0.03 *$ & 0.00 & $0.06^{*}$ & 0.00 \\
\hline Nusa Tenggara & $0.08^{*}$ & 0.02 & $0.04 *$ & 0.01 & $-0.03 *$ & 0.01 & $0.08 *$ & 0.01 \\
\hline Kalimantan & -0.01 & 0.01 & -0.01 & 0.01 & $-0.03 *$ & 0.01 & $0.03 *$ & 0.01 \\
\hline Sulawesi & $0.07 *$ & 0.01 & $0.03 *$ & 0.00 & $-0.02 *$ & 0.01 & $0.06^{*}$ & 0.01 \\
\hline Maluku & $0.25^{*}$ & 0.03 & $0.12 *$ & 0.01 & -0.03 & 0.02 & $0.16^{*}$ & 0.01 \\
\hline Papua & $0.07 *$ & 0.02 & $0.03^{*}$ & 0.01 & $-0.04 *$ & 0.01 & $0.07 *$ & 0.01 \\
\hline $2^{\text {nd }}$ income quintile & $0.11 *$ & 0.01 & $0.04 *$ & 0.00 & $0.03 *$ & 0.01 & $0.03 *$ & 0.00 \\
\hline $3^{\text {rd }}$ income quintile & $0.15^{*}$ & 0.01 & $0.06^{*}$ & 0.00 & $0.05^{*}$ & 0.01 & $0.04 *$ & 0.00 \\
\hline $4^{\text {th }}$ income quintile & $0.18^{*}$ & 0.01 & $0.09 *$ & 0.00 & $0.07 *$ & 0.01 & $0.03 *$ & 0.00 \\
\hline $5^{\text {th }}$ income quintile & $0.23^{*}$ & 0.01 & $0.11 *$ & 0.00 & $0.07 *$ & 0.01 & $0.06^{*}$ & 0.01 \\
\hline Junior secondary school & $-0.02 *$ & 0.01 & $-0.03 *$ & 0.00 & -0.01 & 0.01 & $0.02 *$ & 0.00 \\
\hline High school & 0.01 & 0.01 & $-0.03 *$ & 0.00 & 0.00 & 0.01 & $0.04 *$ & 0.00 \\
\hline University & $0.13^{*}$ & 0.01 & 0.00 & 0.00 & $0.04 *$ & 0.01 & $0.09 *$ & 0.01 \\
\hline Having skill certificate & $0.02 *$ & 0.01 & $-0.01 *$ & 0.00 & -0.01 & 0.01 & $0.04 *$ & 0.00 \\
\hline Good housing conditions & $0.05^{*}$ & 0.01 & $0.03 *$ & 0.00 & $0.03^{*}$ & 0.00 & $0.01 *$ & 0.00 \\
\hline Unemployed & -0.02 & 0.01 & $-0.01 *$ & 0.01 & $-0.01 *$ & 0.01 & $-0.04 *$ & 0.01 \\
\hline $\begin{array}{l}\text { Number of mental health } \\
\text { symptoms present }\end{array}$ & $-0.04 *$ & 0.00 & $-0.01 *$ & 0.00 & $-0.02 *$ & 0.00 & $-0.01 *$ & 0.00 \\
\hline $\begin{array}{l}\text { Number of physical health } \\
\text { issues present }\end{array}$ & $-0.02 *$ & 0.00 & $-0.01 *$ & 0.00 & 0.00 & 0.00 & $-0.01 *$ & 0.00 \\
\hline Healthy lifestyle practices & $0.01 *$ & 0.00 & 0.00 & 0.00 & $0.00^{*}$ & 0.00 & $0.01 *$ & 0.00 \\
\hline $\begin{array}{l}\text { Ratio of working hours to } \\
\text { hours of relaxation }\end{array}$ & $-0.01 *$ & 0.00 & $-0.00 *$ & 0.00 & $-0.00 *$ & 0.00 & $-0.00 *$ & 0.00 \\
\hline $\begin{array}{l}\text { Ability to do relaxing activities } \\
\text { during free time }\end{array}$ & $0.05^{*}$ & 0.00 & $0.02 *$ & 0.00 & $0.01 *$ & 0.00 & $0.02 *$ & 0.00 \\
\hline Good family relationship & $0.03 *$ & 0.00 & $0.01 *$ & 0.00 & $0.02 *$ & 0.00 & $0.01 *$ & 0.00 \\
\hline Feeling lonely and left behind & $-0.03 *$ & 0.01 & $-0.01 *$ & 0.00 & $-0.02 *$ & 0.00 & $-0.00 *$ & 0.00 \\
\hline $\begin{array}{l}\text { Having trust in the } \\
\text { neighborhood }\end{array}$ & $0.01 *$ & 0.00 & $0.00^{*}$ & 0.00 & $0.00^{*}$ & 0.00 & $0.00^{*}$ & 0.00 \\
\hline $\begin{array}{l}\text { Participation in community } \\
\text { activities }\end{array}$ & 0.00 & 0.00 & 0.00 & 0.00 & 0.00 & 0.00 & 0.00 & 0.00 \\
\hline $\begin{array}{l}\text { Being a friendly and sociable } \\
\text { person }\end{array}$ & $0.14^{*}$ & 0.00 & $0.05^{*}$ & 0.00 & $0.03^{*}$ & 0.00 & $0.06^{*}$ & 0.00 \\
\hline $\begin{array}{l}\text { Being able to accept what one } \\
\text { has }\end{array}$ & $0.17^{*}$ & 0.00 & $0.06^{*}$ & 0.00 & $0.04 *$ & 0.00 & $0.07 *$ & 0.00 \\
\hline $\begin{array}{l}\text { Reported air and water } \\
\text { pollution }\end{array}$ & $-0.11 *$ & 0.01 & $-0.02 *$ & 0.01 & $-0.05^{*}$ & 0.01 & $-0.06^{*}$ & 0.03 \\
\hline Being a victim of crime & $-0.06^{*}$ & 0.00 & $-0.03 *$ & 0.00 & $-0.02 *$ & 0.00 & $-0.01 *$ & 0.00 \\
\hline Constant & $3.93 *$ & 0.05 & $1.39 *$ & 0.02 & $1.68^{*}$ & 0.03 & $0.85^{*}$ & 0.02 \\
\hline Adjusted R-Squared & $43 \%$ & & $35 \%$ & & $13 \%$ & & $38 \%$ & \\
\hline
\end{tabular}

$* p$-value $\leq 5 \%$

Source: own calculation 
Good housing conditions are beneficial for Indonesians' SWB. In the Indonesian context, good housing reflects a family's economic status. Hence, families that have good homes with electricity, sanitation and clean water are able to enjoy their lives more than those who do not. As expected, unemployment is harmful for SWB. In all SWB components, unemployed Indonesians were less happy than employed Indonesians. Likewise, poor mental and physical health is detrimental to SWB. Across SWB components, we found those who faced more mental health symptoms and physical issues to be less happy than those facing fewer. In contrast, healthy lifestyle practices benefit SWB. Indonesians who were able to maintain their health through eating healthy foods, exercising regularly, sleeping more, drinking vitamins and having regular medical check-ups have better SWB than others. Longer working hours are not good for Indonesians' SWB, but being able to do relaxing activities such as watching TV and movies, listening to music and karaoke, playing sports, chatting with neighbors or having dinner with family members makes Indonesians happy. Likewise, good family relationships benefit happiness. Respondents who reported having enough time to chat with family members, taking time to do family activities and being respected by spouse and children had better SWB than those who did not. As expected, feeling lonely and left behind was detrimental to happiness.

Neighborhood trust matters for SWB. Respondents who reported trust in close neighbors, religious leaders, community leaders, and members of other ethnicities and religious groups were happier. These findings are particularly important for Indonesia with its religious and ethnic diversity, Indonesia is a country in which social conflicts based on ethnicity and religion often occur. However, null findings were shown for the relationship between democratic participation and SWB, indicating no difference in SWB between persons who were able to articulate their voices within the community and those who were not. Personality, however, matters for SWB. As expected, friendly and sociable people, as well as those who were able to enjoy their lives by accepting what they had experienced greater SWB. Air and water pollution harm SWB. Persons who reported having air and water pollution in the area had lower SWB than those living in healthier areas. Likewise, crimes have a detrimental effect on SWB. We found respondents who had been victims of crime to have lower SWB than others.

\subsection{Robustness analysis}

Figures 3 and 4 show the correlation between SWB and HDI and GDP 2017 across the 34 Indonesian provinces. Null correlations were found. This may indicate that SWB captures different information about well-being and quality of life that may not be captured by both objective measurements. 


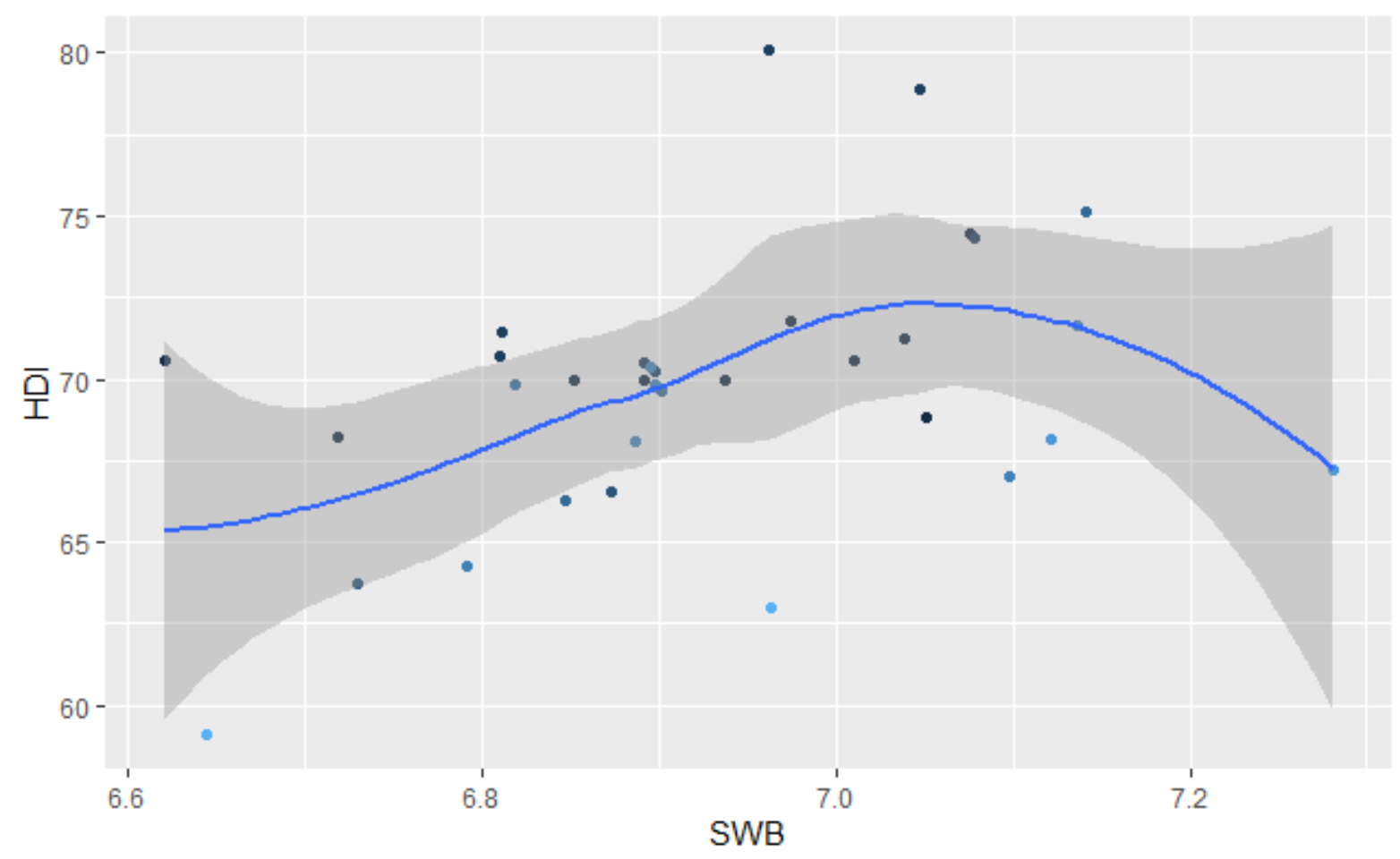

Figure 3. Correlation between SWB and HDI

Source: Indonesia's National Bureau of Statistics, 2018 (graph is created by author)

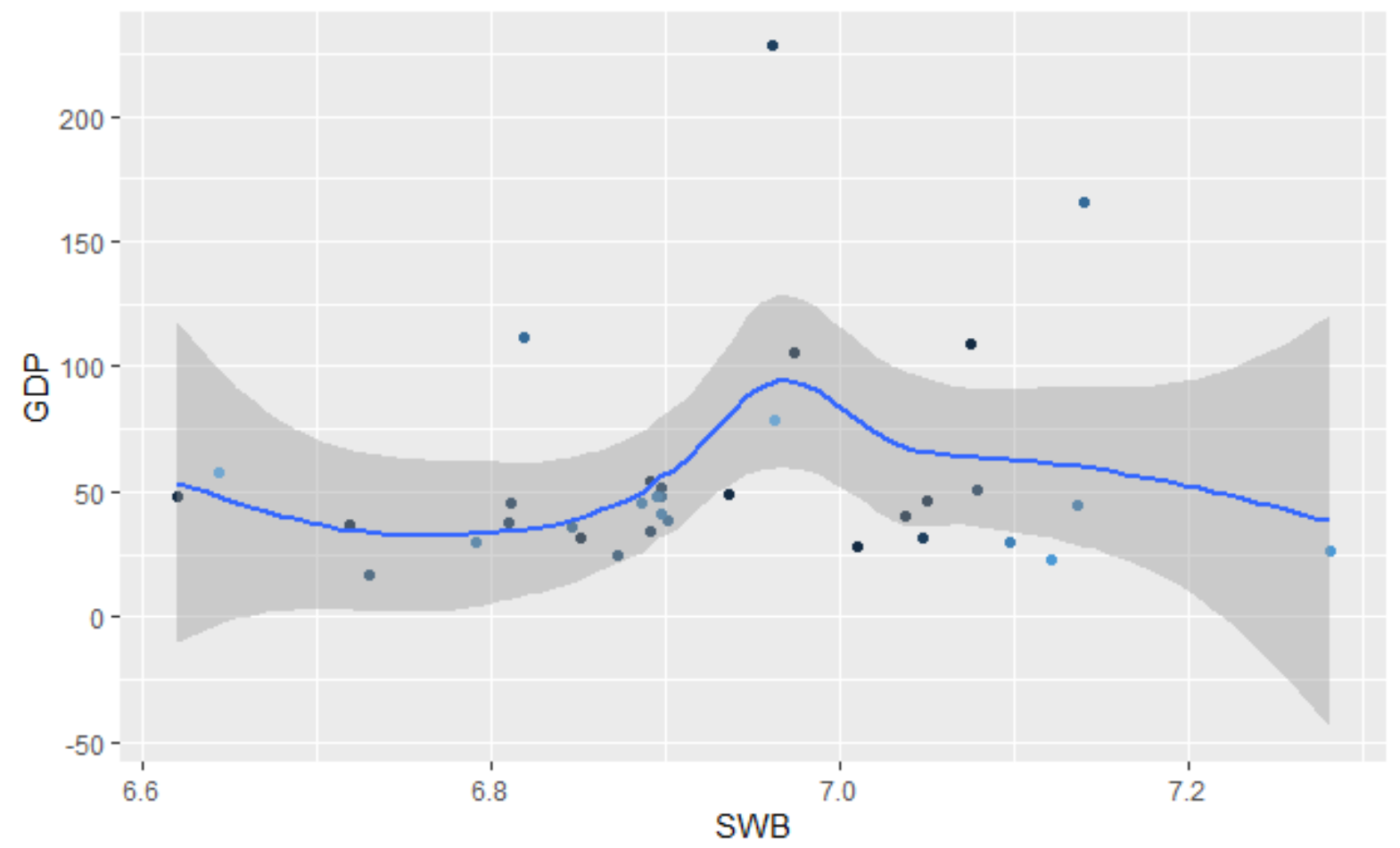

Figure 4. Correlation between SWB and GDP

Source: Indonesia's National Bureau of Statistics, 2018 (graph is created by author) 


\section{Conclusion}

We believe that addressing SWB using a multidimensional measure has importance for monitoring social development progress in a developing country context where current development policy has been focused on economic orientation. Therefore, the demand for official SWB statistics is crucial for informing the public and decision makers. With respect to these purposes, this study aimed to calculate SWB using a multidimensional measure and to identify the demographic and social determinants of SWB in Indonesia.

Our main findings show existing disparities in SWB across provinces in Indonesia. The regional disparities in SWB represent another form of developmental inequality in the country. Studies have well documented deep inequality in terms of economic and human capital development, especially between Papua, West Nusa Tenggara and other provinces in the country (Hanandita \& Tampubolon ,2016, Yusuf et al., 2014,). The vast variations in wellbeing levels among regions reflect heterogeneity in the "capacity and resources of local governments to develop and implement poverty reduction strategies and to provide good public services" (Sumarto et al. 2014).

We found greater SWB to be consistently associated with higher household income, good housing conditions, employment, health status, environmental quality, work-life balance, social connectedness, neighborhood trust, a sense of personal security and a friendly and sociable personality. These findings were consistent and confirmed the results of previous studies (see Visser \& Pozzebon, 2013, Boarini et al., 2012, Kahneman \& Kruger, 2006, Diener \& Seligman, 2004, Oswald et al., 2003, Lane, 2000). However, we also found inconsistent relationships between SWB and household size, education and island of residence. We suggest that the contrasting associations between household size and life evaluation and affect reflect the different functions of the family when considering different aspects of SWB. In Indonesia, having a larger family is often associated with having more social support (Sujarwoto et al., 2018). However, larger families can also be seen as presenting greater life challenges, especially for household heads (Frey \& Stutzer, 2005).

Contrasting associations were also shown for the relationships of junior and high school education with life evaluation and eudemonic well-being. The negative association of junior high and high school education with life evaluation may reflect respondents' dissatisfaction with their education and skills, as we also found a negative association between possession of a skill certificate and life evaluation. As Veenhoven (2010) posited that "formal education is the only capability that does not seem to make people happier". In the Indonesian context, this is particularly true as people who have completed junior high and high school often face difficulties finding jobs. However, its positive association on eudemonic well-being may reflect personal growth and autonomy, as those who graduate from junior high and high school often have greater knowledge and are better able to develop their potential than those who completed only elementary school (Leonor, 2018). Moreover, the contrasting associations of island of residence on life evaluation and affect may reflect differences in life challenges in Jawa and outside Jawa Island (Resosudarmo \& Jotzo, 2009). Negative associations between island of residence and affect may indicate that families living outside Java Island, where they may experience a lack of public amenities, feel that their life challenges are greater than those who live on Jawa, where better public services are generally available (Ezcurra \& Rodriguez, 2014).

Our robustness analysis shows null relationships between SWB and HDI and GDP. We believe that these null relationships indicate that SWB may capture different information about well-being and quality of life than HDI and GDP. Hence, we suggest that SWB may provide an additional understanding of citizens' well-being (Schwartz \& Sortheix, 2018, Fleurbaey, 2009). This is particularly important as the use of HDI and GDP are currently 
being widely criticized by social and economic scholars, yet they are still among the most influential alternatives to income both in policy and research arena. Hence, the importance of SWB in Indonesia highlights important consequences for the current design of the country's welfare policy.

While this analysis has added to our understanding of multidimensional SWB in Indonesia, it also has several limitations. First, like many other measures of well-being, SWB data often face issue of measurement error especially various response biases (Ravallion, 2012). The survey modules were designed to address these issues, but the nature of crosssectional data made it impossible to fully address the risks in this study. Second, the present study did not cover individuals under 18 in the analysis because the survey limited its respondents to individuals 18 and older. Third, this study only covers Indonesian's happiness 2017. Future study may use more recent data.

Despite these limitations, the present study contributes to the SWB literature at least in two ways. Firstly, the adopted OECD SWB measures are able to complement existing objective measures of national social development progress, specifically with regard to income and human development indicators. Our study was able to present an overall picture of Indonesians SWB that is grounded in its citizen's preferences. The findings also provide analysis of a unique mix of social determinants of SWB. This offers a useful complement to existing objective measures in that it can inform life circumstances from citizen perceptions and their emotions. Secondly, the multidimensional measure of SWB used in this study goes beyond the unidimensional SWB measures that have often been used in previous studies. Using three components of SWB, we have been able to provide a more comprehensive picture of SWB in Indonesia.

\section{Acknowledgement}

The author is thankful to the Indonesia Higher Ministry of Education Grant No.: 330.41/UN10.C10/2019 "Model Kebijakan Publik Yang Mengarusutamakan Kebahagiaan Warga" for financial support to carry out this research.

\section{References}

Aksoy, F., \& Bayram, N. (2020). Evaluation of sustainable happiness with Sustainable Development Goals: Structural equation model approach. Sustainable Development, 28(1), 385-392.

Alkire, S., \& Foster, J. (2011). Counting and multidimensional poverty measurement. Journal of public economics, 95(7-8), 476-487.

Aristotle (1985). Nichomachean Ethics. Translated by Terence Irwin. Indianapolis: Hackett Publishing Co.

Atkinson, S., Bagnall, A., Corcoran, R., South, J., \& Curtis, S. (2020). Being well together: individual subjective and community wellbeing. Journal of Happiness Studies, 21(5), 1903-1921.

Bagstad, K., \& Fox, M. (2021). Book review: Replacing GDP by 2030: Towards a common language for the well-being and sustainability community, Rutger Hoekstra, Cambridge University Press, Cambridge (2019). Ecological Economics, 183.

Boarini, R., Murtin, F., Schreyer, P., \& Fleurbaey, M. (2016). Multi-dimensional Living Standards. OECD Statistics: Working Papers Number 05.

BPS. (2017a). Kuisioner SPTK 2017. Jakarta: BPS.

BPS. (2017b). Survey Pengukuran Tingkat Kebahagiaan Indonesia 2017. Jakarta: BPS. 
Cavalletti, B., \& Corsi, M. (2018). "Beyond GDP” Effects on National Subjective Well-Being of OECD Countries. Social Indicators Research, 136(3), 931-966.

Conceição, P., \& Bandura, R. (2008). Measuring subjective well-being: A summary review of the literature. United nations development programme (UNDP) development studies: Working Paper Number 201.

D’Agostino, A., Grilli, G., \& Regoli, A. (2019). The determinants of subjective well-being of young adults in Europe. Applied Research in Quality of Life, 14(1), 85-112.

D'Silva, J., \& Samah, A. (2018). Holistic well-being of Japanese retirees in Malaysia. Journal of International Studies, 11(3).

Deaton, A. (2018). What do self-reports of wellbeing say about life-cycle theory and policy? Journal of public economics, 162, 18-25.

De Neve, J., Diener, E., Tay, L., \& Xuereb, C. (2013). The objective benefits of subjective well-being. World happiness report 2013. New York: UN Sustainable Development Solutions Network.

Diener, E. (2000). Subjective well-being: The science of happiness and a proposal for a national index. American psychologist, 55(1), 34.

Diener, E. (2006). Guidelines for national indicators of SWB and ill-being. Applied research in Quality of Life, 1(2), 151-157.

Diener, E., Oishi, S., \& Lucas, R. (2015). National accounts of subjective wellbeing. American psychologist, 70(3), 234.

Diener, E., Seligman, M., Choi, H., \& Oishi, S. (2018). Happiest people revisited. Perspectives on Psychological Science, 13(2), 176-184.

Di Tella, R., MacCulloch, R., \& Oswald, A. (2003). The macroeconomics of happiness. Review of Economics and Statistics, 85(4), 809-827.

Dolan, P., \& Metcalfe, R. (2011). Measuring subjective well-being for public policy: Recommendations on measures. London: ESRC.

Engelbrecht, H. (2019). National Wealth and the Subjective Well-Being of Nations. In Wealth (s) and Subjective Well-Being (pp. 325-351). Springer.

Ezcurra, R., \& Rodríguez-Pose, A. (2014). Government quality and spatial inequality: A cross-country analysis. Environment and Planning A, 46(7), 1732-1753.

Fleche, S., Smith, C., \& Sorsa, P. (2012). Exploring determinants of subjective well-being in OECD countries. OECD Statistics: Working Papers Number 01.

Fleurbaey, M. (2009). Beyond GDP: The quest for a measure of social welfare. Journal of Economic literature, 47(4), 1029-75.

Frey, B., \& Stutzer, A. (2005). Happiness research: State and prospects. Review of social economy, 63(2), 207-228.

Frey, B. (2020). What are the opportunities for future happiness research? International Review of Economics, 67(1), 5-12.

Ganzach, Y., \& Yaor, E. (2019). The retrospective evaluation of positive and negative affect. Personality and Social Psychology Bulletin, 45(1), 93-104.

Gligorić, M., Gavrilović, B., \& Stanišić, N. (2020). GDP and beyond: Prosperity convergence in the countries of Western and Eastern Europe. Acta Oeconomica, 70(4), 493-511.

Goodman, F., Disabato, D., Kashdan, T., \& Kauffman, S. (2018). Measuring well-being: A comparison of subjective well-being and PERMA. The Journal of Positive Psychology, 13(4), 321-332.

Hamzah, M., Risqiani, R., \& Sofilda, E. (2012). Human Development Quality and Its Problems in Indonesia. OIDA International Journal of Sustainable Development, 5(7), 29-36.

Hanandita, W., \& Tampubolon, G. (2016). Multidimensional poverty in Indonesia: trend over the last decade (2003-2013). Social Indicators Research, 128(2), 559-587. 
Helliwell, J., \& Wang, S. (2010). Trust and well-being. National Bureau of Economic Research Number w15911

Helliwell, J. (2003). How's life? Combining individual and national variables to explain subjective well-being. Economic Modelling, 20, 331-360.

Huppert, F., Marks, N., Clark, A., Siegrist, J., Stutzer, A., Vittersø, J., \& Wahrendorf, M. (2009). Measuring well-being across Europe: Description of the ESS well-being module and preliminary findings. Social Indicators Research, 91(3), 301-315.

Idrus, S., \& Rosida, L. (2020). Poverty In Indonesia: Critical Review. Archives of Business Review-Vol, 8(6).

Iglesias, K., Suter, C., Beycan, T., \& Vani, B. (2017). Exploring multidimensional well-being in Switzerland: Comparing three synthesizing approaches. Social Indicators Research, 134(3), 847-875.

Indonesia Central Bureau of Statistic. (2018). Indonesia's Statistics 2018. Jakarta: BPS.

Iriarte, L., \& Musikanski, L. (2019). Bridging the Gap between the Sustainable Development Goals and Happiness Metrics. International Journal of Community Well-Being, 1(2), 115-135.

Ismyrlis, V., \& Moschidis, E. (2018). Subjective well-being in Europe: a multidimensional statistical analysis of ESS data. International Journal of Happiness and Development, 4(4), 303-316.

Jayawickreme, E., Tsukayama, E., \& Kashdan, T. (2017). Examining the effect of affect on life satisfaction judgments: A within-person perspective. Journal of Research in Personality, 68, 32-37.

Kahneman, D., Krueger, A. B., Schkade, D., Schwarz, N., \& Stone, A. (2004). Toward national well-being accounts. American Economic Review, 94(2), 429-434.

Kahneman, D., \& Krueger, A. B. (2006). Developments in the measurement of subjective well-being. Journal of Economic perspectives, 20(1), 3-24.

Klugman, J., Rodríguez, F., \& Choi, H. (2011). The HDI 2010: new controversies, old critiques. The Journal of Economic Inequality, 9(2), 249-288.

Kurniawan, R., \& Managi, S. (2018). Economic growth and sustainable development in Indonesia: an assessment. Bulletin of Indonesian Economic Studies, 54(3), 339-361.

Kushlev, K., Drummond, D., \& Diener, E. (2020). Subjective Well-Being and Health Behaviors in 2.5 Million Americans. Applied Psychology: Health and Well-Being, 12(1), 166-187.

Kwarciński, T., \& Ulman, P. (2020). Quality of life paradox. Well-being ranking of the selected European countries based on hybrid well-being approach. Economics \& Sociology, 13(2), 160-180.

Lane, R. (2000). The loss of happiness in market democracies. London: Yale University Press.

La Placa, V., McNaught, A., \& Knight, A. (2013). Discourse on well-being in research and practice. International Journal of Well-being, 3(1).

Layard, R. (2006). Happiness and public policy: A challenge to the profession. The Economic Journal, 116(510), C24-C33.

Leonor, M. (2018). Unemployment, Schooling and Training in Developing Countries: Tanzania, Egypt, the Philippines and Indonesia. London: Routledge.

Ludwigs, K., \& Erdtmann, S. (2019). The happiness analyzer-Developing a new technique for measuring subjective well-being. International Journal of Community Well-Being, 1(2), 101-114.

Luhmann, M. (2017). Defining and measuring SWB. Personality Development Across the Lifespan, 197. 
Lui, P., \& Fernando, G. (2018). Development and initial validation of a multidimensional scale assessing subjective well-being: The Well-Being Scale (WeBS). Psychological reports, $121(1), 135-160$.

Mackenzie, C., Karaoylas, E, \& Starzyk, K. (2018). Lifespan differences in a self determination theory model of eudaimonia: A cross-sectional survey of younger, middle-aged, and older adults. Journal of Happiness Studies, 19(8), 2465-2487.

Maddison, D., Rehdanz, K., \& Welsch, H. (2020). Handbook on wellbeing, happiness and the environment. Edward Elgar Publishing.

Maddux, J. (2017). Subjective well-being and life satisfaction: An introduction to conceptions, theories, and measures. Routledge.

McGregor, J., Camfield, L., \& Woodcock, A. (2009). Needs, wants and goals: Well-being, quality of life and public policy. Applied research in Quality of Life, 4(2), 135-154.

Mishchuk, H., Samoliuk, N., \& Bilan, Y. (2019). Measuring social justice in the light of effectiveness of public distributive policy. Administratie si Management Public.

Morrison, P. (2021). Wellbeing and the Region. Handbook of Regional Science, 779-798.

Monni, S., \& Spaventa, A. (2013). Beyond GDP and HDI: Shifting the focus from paradigms to politics. Development, 56(2), 227-231.

Ng, W., \& Diener, E. (2019). Affluence and subjective well-being: does income inequality moderate their associations? Applied Research in Quality of Life, 14(1), 155-170. Ngoo, Y. T., Tey, N. P., \& Tan, E. C. (2015). Determinants of life satisfaction in Asia. Social Indicators Research, 124(1), 141-156.

OECD. (2013). OECD Guidelines on Measuring Subjective Well-being. Paris: OECD Publishing.

OECD. (2017). How's Life? 2017: Measuring Well-being. Paris: OECD Publishing.

Oswald, A., \& Wu, S. (2010). Objective confirmation of subjective measures of human wellbeing: Evidence from the USA. Science, 327(5965), 576-579.

Pancheva, M., Ryff, C., \& Lucchini, M. (2020). An Integrated Look at Well-Being: Topological Clustering of Combinations and Correlates of Hedonia and Eudaimonia. Journal of Happiness Studies, 1-23.

Pradhan, M., Suryahadi, A., Sumarto, S., \& Pritchett, L. (2000). Measurements of poverty in Indonesia, 1996, 1999, and beyond Washington DC: World Bank Publishing.

RAND. (2007). IFLS-4 Survey Description. Santa Monica USA: RAND Publishing.

Ranis, G., \& Stewart, F. (2012). Success and failure in human development, 1970-2007. Journal of Human Development and Capabilities, 13(2), 167-195.

Ravallion, M. (2012). Poor, or just feeling poor? On using subjective data in measuring poverty. Washington DC: World Bank Publishing.

Resosudarmo, B., \& Jotzo, F. (Eds.). (2009). Working with nature against poverty: Development, resources and the environment in eastern Indonesia. Institute of Southeast Asian Studies.

Sameer, Y., Elmassah, S., Mertzanis, C., \& El-Maghraby, L. (2021). Are Happier Nations More Responsible? Examining the Link Between Happiness and Sustainability. Social Indicators Research, 1-29.

Sen, A. (2006). Reason, freedom and well-being. Utilitas, 18(1), 80-96.

Sirgy, M. (2020). Positive Balance at the Developmental Level: Eudaimonia. In Positive Balance (pp. 95-123). Springer.

Skevington, S., \& Böhnke, J. (2018). How is subjective well-being related to quality of life? Do we need two concepts and both measures? Social Science \& Medicine, 206, 22-30.

Sohn, K. (2013). Sources of happiness in Indonesia. The Singapore Economic Review, 58(02), 1350014. 
Stiglitz, J., Sen, A., \& Fitoussi, J. (2009). Commission on the measurement of economic performance and social progress. Report by the Commission on the Measurement of Economic Performance and Social Progress.

Strauss, J., Witoelar, F., Sikoki, B., \& Wattie, A. (2016). User's Guide for the Indonesia Family Life Survey, Wave 5 Santa Monica USA: RAND Publishing.

Sujarwoto, S., Tampubolon, G., \& Pierewan, A. (2018). Individual and Contextual Factors of Happiness and Life Satisfaction in a Low Middle Income Country. Applied research in Quality of Life, 13(4), 927-945.

Sujarwoto, S. (2019). Does Happiness Pays? A Longitudinal Family Life Survey. Applied Research in Quality of Life, 1-23. Sumarto, S., Vothknecht, M., \& Wijaya, L. (2014). 12 Explaining regional heterogeneity of poverty: evidence from a decentralized Indonesia. Regional dynamics in a decentralized Indonesia. Jakarta Indonesia: SMERU Working Paper.

Suryahadi, A., Hadiwidjaja, G., \& Sumarto, S. (2012). Economic growth and poverty reduction in Indonesia before and after the Asian financial crisis. Bulletin of Indonesian Economic Studies, 48(2), 209-227.

Schwartz, S., \& Sortheix, F. (2018). Values and Subjective Well-Being. In E. Diener, S. Oishi, \& L. Tay (Eds.), Handbook of Well-Being. Salt Lake City, UT: Noba Scholar.

Talitha, T., Firman, T., \& Hudalah, D. (2020). Welcoming two decades of decentralization in Indonesia: a regional development perspective. Territory, Politics, Governance, 8(5), 690-708.

Tsurumi, T., Yamaguchi, R., Kagohashi, K., \& Managi, S. (2020). Are cognitive, affective, and eudaimonic dimensions of subjective well-being differently related to consumption? Evidence from Japan. Journal of Happiness Studies, 1-24.

Van Phan, P., \& O'Brien, M. (2019). Multidimensional well-being inequality in a developing country: A case study of Vietnam. Social Indicators Research, 1-27.

Vanhoutte, B. (2014). The multidimensional structure of SWB in later life. Journal of Population Ageing, 7(1), 1-20.

Veenhoven, R. (2010). Capability and happiness: Conceptual difference and reality links. The Journal of Socio-Economics, 39(3), 344-350.

Visser, B., \& Pozzebon, J. (2013). Who are you and what do you want? Life aspirations, personality, and well-being. Personality and Individual differences, 54(2), 266-271.

Yang, L. (2018). Measuring well-being: a multidimensional index integrating subjective wellbeing and preferences. Journal of Human Development and Capabilities, 19(4), 456476.

Yusuf, A., Sumner, A., \& Rum, I. (2014). Twenty years of expenditure inequality in Indonesia, 1993-2013. Bulletin of Indonesian Economic Studies, 50(2), 243-254.

Żemojtel-Piotrowska, M., Piotrowski, J., Cieciuch, J., Adams, B., Osin, E., Ardi, R., Bălţătescu, S., Bhomi, A., Clinton, A., \& De Clunie, G.. (2017). Measurement invariance of Personal Well-being Index (PWI-8) across 26 countries. Journal of Happiness Studies, 18(6), 1697-1711. 